\title{
ANALISIS KEPUASAN WISATAWAN DOMESTIK PADA ATRAKSI DOLPHIN DI PANTAI LOVINA, BULELENG
}

\author{
Kadek Ayu Antari ${ }^{1}$, I Wayan Suardana ${ }^{2}$, LGLK. Dewi ${ }^{3}$ \\ ${ }^{1}$ Email : antariayu11@gmail.com \\ Program Studi Sarjana Industri Perjalanan Wisata, Fakultas Pariwisata, Universitas Udayana \\ ${ }^{2}$ Email : suar.dana@yahoo.co.id \\ Program Studi Sarjana Idustri Perjalanan Wisata, Fakultas Pariwisata, Universitas Udayana \\ 3Email : leli_ipw@unud.ac.id \\ Program Studi Sarjana Industri Perjalanan Wisata, Fakultas Pariwisata, Universitas Udayana
}

\begin{abstract}
Lovina beach is known for the dolphin attraction. Watching dolphin attraction, tourists were transported by boat. As a provider, the helmsman tried to give the best of service to the tourists. However, there were various views of both positive and negative opinions from tourists regarding the services rendered during used. Thus, it must be known to be the dosmetic tourist satisfaction using boat service at Lovina Beach. Data collected by the method of observation, interviews, questionnaires, documentation and literature study. Determination of the sample using purposive sampling technique. Data analysis techniques using customer satisfaction index and importance performance analysis in the form of a Cartesius diagram. The results show that the level of tourist expectation is 4.28 which means it is in the very important category. Furthermore, the value of the captain's performance level obtained a value of 3.77 which was categorized as good. Calculation of the gap value shows the gap between the level of expectation and the level of performance with the acquisition of a value of -0.51 . Analysis of the level of tourist satisfaction based on the calculation of the customer satisfaction index shows that tourists are satisfied with a value of $75.54 \%$. There are 4 indicators that need to be prioritized to be improved, including the availability of life jackets, responsibility for the safety of tourists, a sense of security while using a boat and the helmsman has the ability to create good relationships with tourists.
\end{abstract}

Abstrak : Pantai Lovina dikenal dengan adanya atraksi dolphin. Untuk menyaksikan atraksi dolphin, wisatawan diantarkan menggunakan perahu. Sebagai penyedia jasa, nahkoda berusaha memberikan pelayanan yang terbaik kepada wisatawan. Namun, terdapat berbagai pendapat baik pendapat positif maupun negatif dari wisatawan mengenai pelayanan yang telah diberikan selama menggunakan jasa perahu. Maka itu, perlu diketahui tingkat kepuasan wisatawan domestik pengguna jasa perahu di Pantai Lovina, Buleleng. Data dikumpulkan dengan metode observasi, wawancara, penyebaran kuesioner, dokumentasi dan studi pustaka. Penentuan sampel menggunakan teknik purposive sampling. Teknik analisis data menggunakan customer satisfaction index dan importance performance analysis. Hasil menunjukkan bahwa tingkat harapan wisatawan memperoleh nilai 4,28 yang artinya berada di kategori sangat penting. Selanjutnya nilai tingkat kinerja nahkoda memperoleh nilai sebesar 3,77 yang dikategorikan baik. Perhitungan nilai gap menunjukkan adanya kesenjangan antara tingkat harapan dengan tingkat kinerja dengan perolehan nilai sebesar $-0,51$ yang artinya harapan wisatawan lebih tinggi dibandingkan dengan kinerja nahkoda. Analisis tingkat kepuasan wisatawan berdasarkan perhitungan customer satisfaction index menunjukkan bahwa wisatawan merasa puas dengan nilai sebesar 75,54\%. Terdapat 4 indikator yang perlu diprioritaskan untuk diperbaiki diantaranya yaitu ketersediaan life jacket, bertanggung jawab atas keselamatan wisatawan, rasa aman selama menggunakan perahu dan nahkoda memiliki kemampuan untuk menciptakan hubungan yang baik dengan wisatawan.

Keywords : tourist satisfaction, service quality, lovina beach. 


\section{PENDAHULUAN}

Pariwisata merupakan industri yang berkembang pesat di Indonesia. Hal ini dapat dibuktikan dengan adanya perbaikanperbaikan yang dilakukan oleh pemerintah dan pihak swasta. Selain sebagai penyumbang devisa, pariwisata diandalkan dalam meningkatkan pemasukan yang ada di daerahdaerah yang memiliki destinasi wisata yang mampu menarik minat wisatawan. Salah satu daerah tersebut adalah Pulau Bali.

Bali merupakan sebuah pulau yang terletak pada wilayah tengah Indonesia yang mempunyai julukan paradise island, karena memiliki banyak potensi wisata menarik mulai dari alam, budaya hingga kuliner yang beraneka ragam. Masing-masing kabupaten yang berada di Bali memiliki ciri khas tersendiri. Kabupaten Buleleng adalah salah satu kabupaten di Bali yang memiliki banyak potensi pariwisata baik wisata budaya, wisata spiritual, wisata sejarah maupun wisata alam. Jumlah kunjungan wisatawan ke Kabupaten Buleleng terus mengalami peningkatan. Wisatawan yang berkunjung ke Kabupaten Buleleng mengalami peningkatan sejak tahun 2014 sampai 2018. Peningkatan tersebut dapat dinilai secara positif sebagai kemajuan pengembangan pariwisata di Kabupaten Buleleng.

Kabupaten Buleleng dengan potensi wisata yang dimiliki berhasil meraih penghargaan, diantaranya Yokatta Wonderfull Indonesia Tourism Award 2018 yang merupakan penghargaan pariwisata kepada kepala daerah maupun daerah yang terus berupaya memajukan potensi pariwisata yang dimiliki (dikutip dari https://bulelengkab.go.id). Selain itu, 4 desa wisata yang ada di Kabupaten Buleleng berhasil meraih penghargaan kategori silver dan kategori bronze dalam acara Anugerah Desa Wisata 2017 (dikutip dari https://www.nusabali.com). Salah satu desa wisata yang mendapat penghargaan adalah Desa Kalibukbuk yang terkenal dengan wisata Pantai Lovina. Pantai Lovina merupakan salah satu Kawasan Strategis Pariwisata Nasional (KSPN) yang menjadi maskot wisata di Kabupaten Buleleng (dikutip dari Fajar.com). Jumlah kunjungan wisatawan domestik ke Pantai Lovina mengalami fluktuasi. Tahun 2014 dengan jumlah kunjungan wisatawan mencapai 29.924. Selanjutnya, tahun 2015 jumlah wisatawan mengalami kenaikan, yaitu 44.668 dengan persentase kenaikan sebesar 49,27\%. Pada tahun 2016, jumlah kunjungan wisatawan mengalami penurunan, yaitu 39.387 dengan persentase sebesar $-11,82 \%$. Pada tahun 2017, jumlah kunjungan wisatawan kembali mengalami peningkatan sebesar 23,96\% dari tahun 2016. Namun, pada tahun 2018 jumlah kunjungan wisatawan kembali menurun sebesar $-53,53 \%$ dengan jumlah 22.687 wisatawan.

Pantai Lovina menyuguhkan wisata alam pantai yang memiliki potensi seperti keindahan pantai dan keunikan bawah laut yang dapat dikembangkan melalui wisata bahari, seperti snorkeling, diving, sailing, serta atraksi dolphin yang merupakan ikon pariwisata Lovina. Untuk melihat atraksi dolphin, wisatawan membutuhkan transportasi untuk sampai di tengah laut. Transportasi selain sebagai sarana bagi perekonomian, juga merupakan alat atau sarana bagi wisatawan untuk menuju ke suatu daerah tujuan wisata (Suardana, dkk 2013). Adapun jenis transportasi yang digunakan adalah transportasi laut berupa perahu.

Perahu sebagai alat transportasi yang digunakan wisatawan untuk menyaksikan atraksi dolphin diharapkan dapat memenuhi kebutuhan wisatawan guna memberikan rasa puas kepada wisatawan selama menggunakan jasa perahu di Pantai Lovina. Menurut Juwandi (2004), salah satu faktor pendorong kepuasan konsumen adalah peningkatan kualitas pelayanan. Semakin baik kualitas pelayanan yang diberikan, sikap pengguna jasa akan semakin puas dengan layanan yang telah diterima dari penyedia jasa. Sebagai penyedia jasa perahu, nahkoda berusaha memberikan pelayanan yang terbaik kepada wisatawan. Namun, pasti masih ada kendala ketidak puasan wisatawan berupa adanya keluhan mengenai pelayanan yang diberikan oleh nahkoda perahu.

Berdasarkan hasil wawancara singkat dengan beberapa wisatawan yang telah menggunakan perahu di Pantai Lovina, mengatakan pelayanan yang diberikan nahkoda perahu masih kurang optimal. Wisatawan mengeluhkan pelayanan dari segi keamanan dan keselamatan wisatawan yang kurang diperhatikan oleh nahkoda perahu, serta nahkoda perahu yang kurang komunikatif. Hal ini memberikan nilai negatif 
bagi pelayanan nahkoda perahu di Pantai Lovina. Namun, selain pendapat negatif ada pula pendapat positif yang diberikan oleh beberapa wisatawan yang dikutip dari trip advisor. Berdasarkan beberapa pendapat baik positif dan negatif tersebut, perlu diketahui kepuasan wisatawan pengguna perahu pada atraksi dolphin di Pantai Lovina terhadap pelayanan yang diberikan nahkoda perahu. Hal ini karena kepuasan wisatawan merupakan salah satu faktor penentu dari keberhasilan suatu usaha.

Wisatawan yang puas dengan pelayanan yang diberikan nahkoda memiliki kemungkinan untuk kembali atau merekomendasikan pelayanan yang telah didapatkannya kepada kerabat-kerabatnya. Maka itu, penting bagi nahkoda perahu untuk memperhatikan dan memahami antara harapan yang diinginkan oleh wisatawan dan kinerja pelayanan yang diberikan guna menciptakan kepuasan wisatawan.

Selain itu, perahu juga merupakan alat transportasi satu-satunya yang digunakan di Pantai Lovina untuk membawa wisatawan menyaksikan atraksi dolphin di tengah laut. Maka itu, perlu diketahui pendapat wisatawan tentang kekurangan pelayanan yang diberikan oleh nahkoda sehingga nahkoda perahu mampu memperbaiki atau meningkatkan layanan-layanan yang dianggap kurang oleh wisatawan. Dengan perbaikan dan peningkatan kualitas pelayanan, wisatawan akan merasa puas di masa mendatang dan dapat membantu meningkatkan jumlah kunjungan wisatawan ke Pantai Lovina.

\section{METODE}

Studi ini dilakukan di Pantai Lovina yang terletak di Desa Kalibukbuk, Kabupaten Buleleng. Pengukuran kepuasan berdasarkan variabel kualitas pelayanan yang terdiri dari tangibles (bukti fisik), reliability (kehandalan), responsiveness (daya tanggap), assurance (jaminan), dan empathy (empati). Teknik pengumpulan data dilakukan dengan observasi, wawancara, kuesioner, studi kepustakaan, dan dokumentasi. Teknik penentuan sampel menggunakan purposive sampling dengan menentukan jumlah sampel mengacu pada rumus yang dikemukakan oleh Hair, et al (2006:166) yaitu mengalikan 5 atau 10 dengan jumlah indikator. Sehingga didapatkan hasil perhitungan $5 \times 20$ indikator yaitu 100 responden. Studi ini menggunakan skala likert untuk mengukur sikap atau pendapat seseorang atau sejumlah kelompok terhadap sebuah fenomena sosial yang dimana jawaban setiap item instrumen mempunyai gradasi dari sangat positif sampai sangat negatif (Sugiyono, 2012).

Adapun teknik analisis data yang digunakan adalah customer satisfaction index dan importance performance analysis. Nilai CSI dibagi dalam lima kriteria yang dapat dilihat pada Tabel 1.

Tabel 1. Kriteria Nilai Customer Service Index

\begin{tabular}{cc}
\hline Nilai CSI & Kritesia CSI \\
\hline $81 \%-100 \%$ & Sangat Puas \\
\hline $61 \%-80 \%$ & Puas \\
\hline $41 \%-60 \%$ & Cukup Puas \\
\hline $21 \%-40 \%$ & Kurang Puas \\
\hline $0 \%-20 \%$ & Tidak Puas
\end{tabular}

Sumber : Tabel Index CSI Fitriyanto, 2018.

\section{HASIL DAN PEMBAHASAN}

\section{Karakteristik Responden}

Berdasarkan jenis kelamin wisatawan pengguna jasa perahu pada atraksi dolphin di Pantai Lovina, Buleleng didominasi oleh perempuan dengan persentase $66 \%$. Berdasarkan asal, kebanyakan wisatawan dari DKI Jakarta dengan persentase $38 \%$. Hal ini karena Jakarta merupakan daerah yang padat dan hampir setiap hari terkena macet, sehingga masyarakat memilih untuk berlibur ke Bali khususnya Pantai Lovina.

Untuk karakteristik responden berdasarkan umur mayoritas adalah rentang umur 17-27 tahun. Pada rentang umur tersebut merupakan umur yang masih produktif untuk melakukan perjalanan maupun kegiatankegiatan lainnya. Karakteristik berdasarkan pekerjaan terbanyak adalah sebagai pelajar/mahasiswa dengan persentase $45 \%$. Selanjutnya, karakteristik responden berdasarkan status kebanyakan belum menikah yang memiliki presentase $78 \%$. Karakteristik berdasarkan lama kunjungan yang memiliki persentase paling tinggi sebesar $70 \%$ adalah adalah $<1$ minggu.

Berdasarkan tempat menginap kebanyakan memilih hotel dengan persentase 45\%. Selanjutnya karakteristik berdasarkan frekuensi berkunjung kebanyakan pertama kali dengan persentase $64 \%$. Terakhir, karakteristik 
responden berdasarkan sumber informasi mengenai Pantai Lovina didominasi dari teman dengan perolehan sebesar $49 \%$.

\section{Tingkat Harapan Wisatawan Pengguna Jasa Perahu Pada Atraksi Dolphin di Pantai Lovina, Buleleng}

Tingkat harapan wisatawan didapatkan dengan menyebarkan kuesioner kepada wisatawan pengguna jasa perahu di Pantai Lovina sebanyak 100 kuesioner mengenai variabel kualitas pelayanan. Hasil menunjukkan bahwa life jacket meperoleh skor rata-rata tertinggi untuk tingkat harapan wisatawan yaitu sebesar 4,47 yang dikategorikan sangat penting. Hal ini dikarenakan life jacket memiliki peran sangat penting bagi keselamatan wisatawan yang hendak melihat atraksi dolphin menggunakan perahu ke tengah laut. Sedangkan untuk indikator yang memiliki skor rata-rata terendah adalah ketepatan durasi melihat atraksi dolphin dengan skor rata-rata 3,94 yang berada pada kategori penting. Secara keseluruhan skor rata-rata tingkat harapan dari 20 indikator adalah sebesar 4,28. Jadi, tingkat harapan wisatawan dikategorikan sangat penting.

\section{Tingkat Kinerja Nahkoda Perahu Pada Atraksi Dolphin di Pantai Lovina, Buleleng}

Penilaian kinerja nahkoda dilakukan oleh 100 wisatawan pengguna perahu dengan mengisi kuesioner, kemudian skala likert digunakan untuk mengukur sejauh mana kinerja nahkoda perahu. Hasil menunjukkan bahwa indikator yang memiliki skor tertinggi pada nahkoda melayani dengan tidak diskriminatif yang memperoleh skor sebesar 4,38 artinya kinerja tersebut berada dikategori sangat baik. Sedangkan untuk indikator yang memperoleh skor terendah adalah ketersediaan life jacket yaitu sebesar 3,18 dengan kategori cukup baik. Nahkoda perlu memperhatikan indikator ini dan memperbaiki kinerjanya guna menunjang kepuasan wisatawan. Hasil secara keseluruhan dari 20 indikator kualitas pelayanan memperoleh skor sebesar 3.77. Hal ini berarti bahwa kinerja nahkoda perahu pada atraksi dolphin di Pantai Lovina secara keseluruhan dikategorikan baik.

\section{Analisis Kesenjangan (Gap) Antara Harapan dan Kinerja}

Nilai gap diperoleh dari hasil perhitungan antara skor rata-rata kinerja dikurangi dengan skor rata-rata harapan dari setiap indikator. Apabila nilai kepuasan negatif $\quad(<0)$ menunjukkan adanya kesenjangan antara harapan dan kinerja, sedangkan apabila nilai kepuasan positif $(>0)$ menunjukkan kualitas pelayanan telah melebihi tingkat kepuasan wisatawan. Bila nilai kepuasan sama dengan nol $(=0)$ menunjukkan kualitas pelayanan telah sesuai dengan harapan wisatawan. Perhitungan dari analisis kesenjangan (gap) antara harapan dan kinerja memperoleh hasil $-0,51$, artinya tingkat harapan lebih tinggi dibandingkan tingkat kinerja. Dilihat dari konsep kepuasan, apabila kinerja lebih tinggi dibandingkan dengan harapan maka wisatawan akan merasa sangat puas, apabila nilai kinerja sama dengan harapan maka wisatawan merasa puas dan apabila nilai kinerja berada di bawah nilai harapan, maka wisatawan merasa kurang puas. Hal ini berarti wisatawan cenderung kurang puas dengan beberapa pelayanan nahkoda perahu di Pantai Lovina.

\section{Analisis Tingkat Kepuasan Wisatawan Pengguna Jasa Perahu Pada Atraksi Dolphin di Pantai Lovina, Buleleng}

Tingkat kepuasan wisatawan domestik terhadap hasil kinerja nahkoda perahu pada atraksi dolphin di Pantai Lovina, Buleleng secara menyeluruh diketahui melalui perhitungan customer satisfaction index (CSI). Hasil perhitungan didapatkan nilai sebesar $75,54 \%$ menunjukkan bahwa wisatawan puas dengan kualitas pelayanan nahkoda. Hal ini berdasarkan dari tabel interpretasi customer satisfaction index yang menunjukkan bahwa nilai CSI yang dihasilkan pada penelitian ini berada pada rentang nilai $61 \%-80 \%$ yang artinya kriteria tersebut adalah puas. Nahkoda sebaiknya terus melakukan perbaikan terhadap kualitas pelayanan agar wisatawan merasa sangat puas akan pelayanan yang diberikan secara keseluruhan. Hal ini karena masih ada $24,46 \%$ wisatawan yang belum puas. Selain itu, hal ini juga didukung oleh nilai gap antara tingkat harapan wisatawan dengan kinerja nahkoda yang memiliki nilai negatif yang artinya masih ada kesenjangan antara harapan wisatawan dengan kinerja nahkoda. 


\section{Importance Performance Analysis}

Analisis ini mengaitkan antara harapan (importance) wisatawan pengguna jasa perahu dengan kinerja (performance) nahkoda perahu yang dirasakan wisatawan. Hasil importance performance analysis (IPA) dalam studi ini disajikan dalam bentuk diagram kartesius. Diagram kartesius ini dibagi kedalam 4 kuadran, yaitu kuadran A, B, C, dan D. Untuk menjabarkan setiap indikator ke dalam diagram kartesius data yang diperlukan adalah skor rata-rata kinerja dan skor rata-rata harapan. Letak indikator-indikator yang mempengaruhi kepuasan wisatawan domestik pengguna jasa perahu pada atraksi dolphin di Pantai Lovina, Buleleng dapat dilihat di diagram kartesius pada Gambar 1.

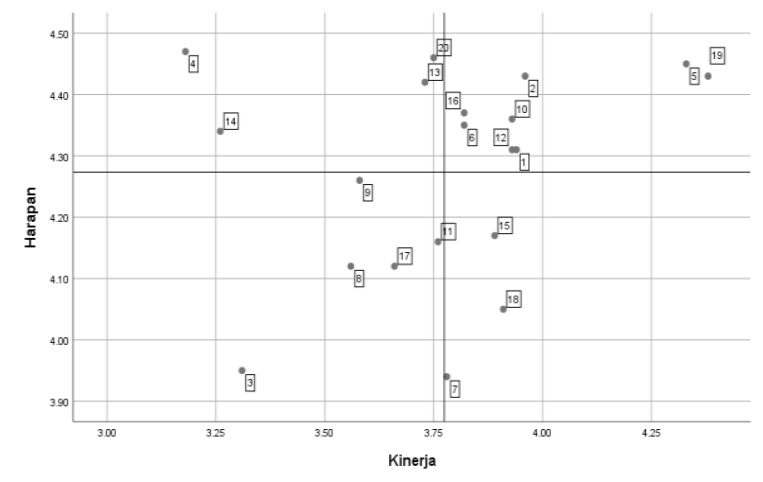

Gambar 1. Diagram Kartesius

Berdasarkan Gambar 1, diketahui letak titik indikator-indikator yang mempengaruhi kepuasan wisatawan domestik pengguna jasa perahu pada atraksi dolphin di Panta Lovina, Buleleng terbagi dalam empat kuadran yang akan dipaparkan sebagai berikut.

\section{Kuadran A}

Menunjukkan indikator yang dianggap penting bagi wisatawan namun kinerja nahkoda belum memuaskan bagi wisatawan. Jadi indikator ini perlu diprioritaskan oleh nahkoda untuk diperbaiki. Adapun indikator yang berada pada kuadran A adalah sebagai berikut:

1. Ketersediaan Life Jacket.

2. Bertanggung jawab atas keselamatan wisatawan.

3. Rasa aman selama menggunakan perahu.
4. Nahkoda memiliki kemampuan untuk menciptakan hubungan baik dengan wisatawan.

\section{Kuadran B}

Menunjukkan indikator-indikator yang penting bagi wisatawan dan kinerjanya juga memuaskan. Berikut adalah indikatorindikator yang ada pada kuadran B:

1. Kebersihan Perahu.

2. Kenyamanan wisatawan menggunakan perahu.

3. Nahkoda memiliki perahu yang layak digunakan.

4. Penggunaan bahasa yang komunikatif dalam memberikan informasi.

5. Nahkoda berinisiatif untuk membantu wisatawan.

6. Nahkoda cepat tanggap dalam menghadapi masalah yang timbul.

7. Nahkoda mampu menumbuhkan rasa percaya wisatawan.

8. Nahkoda melayani dengan tidak diskriminatif.

\section{Kuadran C}

Menunjukkan indikator-indikator yang dianggap tingkat kepentingannya tidak mendapat penilaian tinggi, namun kinerjanya memiliki nilai yang cukup baik. Dapat dilihat indikator-indikator yang terletak pada kuadran $\mathrm{C}$ adalah sebagai berikut:

1. Penampilan nahkoda.

2. Ketepatan informasi yang diberikan nahkoda perahu kepada wisatawan.

3. Pelayanan sesuai dengan tarif yang dikenakan.

4. Nahkoda mengerti dengan cepat keinginan wisatawan.

5. Kesopanan nahkoda berkomunikasi dengan wisatawan.

\section{Kuadran D}

Menunjukkan indikator kurang diharapkan oleh wisatawan namun nahkoda melakukan kinerjanya dengan sangat baik sehingga dinilai terlalu berlebihan. Berikut adalah indikator-indikator yang terletak pada kuadran D:

1. Ketepatan durasi melihat atraksi dolphin.

2. Nahkoda mendengarkan keluhan wisatawan dengan baik.

3. Memiliki pengetahuan dalam menjawab setiap pertanyaan wisatawan. 


\section{SIMPULAN DAN SARAN Simpulan}

Berdasarkan pembahasan di atas, diketahui bahwa tingkat harapan wisatawan pengguna jasa perahu pada atraksi dolphin di Pantai Lovina, Buleleng memperoleh skor rata-rata sebesar 4,28 dengan kategori sangat penting. Diketahui juga perolehan skor ratarata tingkat kinerja nahkoda perahu sebesar 3,77 yang dikategorikan baik. Perhitungan nilai kesenjangan (gap) mendapatkan hasil negatif $(<0)$ yaitu $-0,51$ yang artinya terdapat kesenjangan antara kinerja nahkoda dan harapan wisatawan.

Berdasarkan hasil perhitungan menggunakan customer satisfaction index, didapatkan tingkat kepuasan wisatawan pengguna jasa perahu pada atraksi dolphin di Pantai Lovina, Buleleng sebesar 75,54\% yang termasuk ke dalam kategori Puas. Terdapat 4 indikator yang perlu diprioritaskan untuk diperbaiki diantaranya yaitu ketersediaan life jacket, bertanggung jawab atas keselamatan wisatawan, rasa aman selama menggunakan perahu dan nahkoda memiliki kemampuan untuk menciptakan hubungan yang baik dengan wisatawan.

\section{Saran}

Dalam studi ini hanya membahas mengenai kepuasan wisatawan pengguna jasa perahu berdasarkan kualitas pelayanan nahkoda. Diharapkan selanjutnya membahas lebih lanjut dan mendalam seperti menambah variabel serta jumlah responden, serta dapat membahas mengenai minat berkunjung kembali wisatawan pengguna jasa perahu pada atraksi dolphin di Pantai Lovina, Buleleng. Selain itu, peneliti selanjutnya dapat meneliti wisatawan milenial karena dilihat dari karakteristik wisatawan berdasarkan umur yang mendominasi berkunjung dan menggunakan jasa perahu adalah umur 17 tahun-27 tahun.

Nahkoda perahu harus memperbaiki kinerja pada indikator-indikator yang dianggap kurang oleh wisatawan seperti, mengoptimalkan kualitas dan kuantitas ketersediaan life jacket pada setiap perahu yang dimiliki nahkoda, meningkatkan tanggung jawab atas keselamatan wisatawan saat menggunakan perahu untuk melihat atraksi dolphin di tengah laut dan meningkatkan kinerja pada indikator lainnya yang menjadi prioritas utama untuk diperhatikan.

Selain memperbaiki dan meningkatkan indikator-indikator yang menjadi prioritas utama untuk diperbaiki, nahkoda disarankan untuk dapat mempertahankan indikatorindikator yang telah dianggap memuaskan oleh wisatawan seperti, kebersihan perahu, kenyamanan wisatawan menggunakan perahu, nahkoda memiliki perahu yang layak digunakan dan indikator lainnya. 


\section{Kepustakaan}

Adnyani, Kadek Utami Wirya. 2015. Analisis Kepuasan Wisatawan Lanjut Usia Terhadap Produk Wisata Di Kawasan Wisata Ubud. Jurnal IPTA Vol. 3. No. 1.

Dinas Pariwisata Pemerintah Kabupaten Buleleng. 2018. Buleleng Raih Yokatta Wonderful Indonesia Tourism Award 2018. https://dispar.bulelengkab.go.id. Diakses tanggal 30 september 2018, 21.17 WITA

Dinas Pariwisata Pemerintahan Kabupaten Buleleng. Rekapan Data Kunjungan Wisatawan. https://dispar.bulelengkab.go.id. Diakses pada tanggal 23 Maret 2019, pukul 18.32 WITA

Fitriyanto, M. Abdul. 2018. Analisis Tingkat Kepuasan Konsumen Terhadap Kualitas Layanan Dengan Metode Service Quality Dan Importance Performance Analysis, Studi Kasus Pada PT. Lion Superindo. Laporan Akhir. Yogyakarta. Universitas Islam Indonesia.

Juwandi, Hendy Irawan. 2004. Kepuasan Pelayanan Jasa. Erlangga Jakarta.

NusaBali.com. 2017. Empat Desa Wisata Kabupaten Buleleng Dapat Penghargaan.

https://www.nusabali.com. Diakses tanggal 30 september 2018, 21.19 WITA.

Suardana, I Wayan, I Ketut Suwena, Luh Gede Leli Kusuma Dewi. 2013. Tingkat Kepuasan Wisatawan Terhadap Kualitas Pelayanan Shuttle Bus Komotra Bali Di Central Park Kuta. Jurnal IPTA, Vol. 1. No 1, 2013.

Sugiyono. 2012. Metode Penelitian Kuantitatif Kualitatif dan $R \& D$. Bandung: Alfabeta.

Syah, Syukryan Abrar. 2018. Faktor Kepuasan Wisatawan Pengguna Transportasi Laut Dari Bali Ke Gili Trawangan. Laporan Tugas Akhir. Denpasar. Universitas Udayana. 